\title{
Implementasi Model Inkuiri dalam Pembelajaran Soccer Like Games untuk Meningkatkan Jumlah Waktu Aktif Belajar Siswa
}

\author{
Irvan Hilmy Suryaman
}

SDN 062 Ciujung,

Info Artikel
SejarahArtikel:
Diterima Juli 2019
Disetujui September 2019
Dipublikasikan Oktober 2019

Keywords:

Jumlah Waktu Aktif Belajar, Model Inkuiri, Soccer Like Games,

\begin{abstract}
Abstrak
Studi ini dilatar belakangi oleh rendahnya waktu aktif belajar pada keterampilan bermain soccer like games dan kurangnya penerapan model-model pembelajaran Pendidikan jasmani di Sekolah Dasar maka peneliti dalam upaya mengatasi permasalahan tersebut peneliti menerapkan salah satu strategi pembelajaran yaitu Implementasi Model Inquiri Dalam Pembelajaran Soccer like-games untuk Meningkatkan Jumlah Waktu Aktif Belajar (JWAB) Siswa Kelas V SD yang bertujuan untuk mengetahui peningkatan keterampilan bermain Soccer like-games kelas V SDN 062 Ciujung Kota Bandung. Metode penelitian yang digunakan yaitu Penelitian Tindakan Kelas (PTK). Objek dalam penelitian ini yaitu Sekolah Dasar Negeri Ciujung Kota Bandung. Subjek dalam penelitian ini sebanyak 30 siswa. Hasil observasi menunjukan tingkat keterampilan bermain siswa mencapai $(80,00 \%)$ dan pada jumlah waktu aktif belajar berjumlah $(76,00 \%)$. Dari data hasil penelitian yang telah dilakukan dapat disimpulkan bahwa mengalami peningkatan presentase setiap siklus dan tindakannya sehingga dengan penerapan model inkuiri pada permainan Soccer like-games dapat meningkatkan keterampilan bermain siswa dengan waktu belajar.
\end{abstract}

\begin{abstract}
The background of this study was the low level of play skill and also the application of learning models of physical education at primary schools. In order to resolve those problems, the researchers applied a strategy called "The Implementation of Inquiry Model in Learning Soccer like games to Increase The Amount of Active Learning Time for The 5th Grade Students". The goal of this research was to know the increasing of the 5th grade students' skills at SDN 062 Ciujung, Bandung City in playing soccer like games. Classroom Action Research was used as the method of this research. The object of this research was SDN Ciujung Bandung City. There were 30 students participated as the subject of this research. The result of this achieved $(80,00 \%)$ for the amount of active learning time at $(76,00 \%)$. From the previous data, it could be concluded that there were some increasing for each cycles and actions and so the application of inquiry model for soccer like games could increase students' skill with the learning time.
\end{abstract}

*Alamat korespondensi : Jl. Lapangan Supratman No. 7, Kota Bandung
$\begin{array}{ll}\text { E-mail } & \text { irvanhilmysuryaman96@gmail.com }\end{array}$ 


\section{PENDAHULUAN}

Pendidikan jasmani merupakan bagian penting dari proses pendidikan. Melalui pendidikan jasmani yang diarahkan dengan baik, anak akan mengembangkan keterampilan yang berguna bagi untuk memanfaatkan waktu senggang, terlibat dalam aktivitas yang kondusif untuk mengembangkan hidup sehat, berkembang secara sosial, dan menyumbang pada kesehatan fisik dan mentalnyaPelajaran pendidikan jasmani tidak kalah penting dibandingkan dengan pelajaran lainnya (Mahendra 2015). Hasil pengamatan penulis dilapangan, keterampilan bermain siswa pada pembelajaran soccer like games masih rendah. Kepiawaian guru dalam memanage pembelajaran sangat diperlukan, terutama untuk meningkatkan minat dan partisipasi siswa dalam pembelajaran penjas.

Soccer like games adalah permainanpermainan yang menyerupai permaiana sepakbola. Menyerupai artinya cara memainkan serta gerak yang dilakukanya sama seperti pada gerakan permainan sepakbola, pembedanya hanya terletak pada pendekatan permainan serta bentuk bentuk pembelajaran, serta aturan dan perlengkapan yang dapat dimodifikasi seluas-luasnya demi kepentingan keterlibatan peserta didik dalam aktivitas pemebelajaran.Dengan soccer like games diharapkan partisipasi belajar siswa dapat meningkat karena soccer like games tidak hanya diminati siwa lakilaki saja, melainkan siswa perempuan juga dapat ikut terlibat untuk berperan serta dalam aktifitas pembelajaran. Sehingga semua siswa merasa dilibatkan dalam kegiatan pembelajaran tampa terkecuali. Selain itu, permainan ini tidak harus memiliki keahlian khusus dalam bermain dan alat-alat yang digunakan sangat sederhana dan mudah didapat karena benda apapun yang ada di sekitaran siswa atau dilingkungan sekolah dapat dijadikan dalam pembelajaran ini. Aktivitas permainan soccer like games yang diberikan kepada siswa sekolah dasar diharapkan ikut membantu dalam pencapaian tujuan pendidikan seperti meningkatkan hubungan akrab dengan guru, meningkatkan siswa untuk mengikuti pembelajaran terciptanya kondusif dalam pelaksanaan pendidikan serta memenuhi kebutuhan dalam pertumbuhan dan pengembangan siswa kearah yang sempurna (Bahagia. 2010).

Model inkuiri dipilih karena dengan menerapkan model tersebut pada umumnya akan lebih efektif apabila dilaksanakan dengan proses informasi. Hal ini dikarenakan model proses informasi menekankan bagaimana seseorang berpikir dan bagaimana dampaknya terhadap cara-cara mengolah informasi. Selain itu Metode inquiry adalah metode yang melibatkan peserta didik dalam proses pengumpulan data dan pengujian hipotesis (Endarti. 2016). Inkuiri adalah the process of infestigating a problem (proses penyelidikan masalah) sedangkan secara terminologi inquiry berarti proses berfikir kritis dan analisis untuk mencari dan menemukan sendiri jawaban dari satu masalah yang dipertanyakan, (Lahadisi. 2014). Defenisi lain yang diajukan oleh bahwa strategi pembelajaran inkuiri adalah cara penyampaian bahan pengajaran dengan memberi kesempatan kepada siswa untuk belajar mengembangkan potensi intelektualnya dalam jalinan kegiatan yang disusunya sendiri untuk menemukan sesuatu sebagai jawaban yang meyakinkan terhadap permasalahan yang di hadapkan kepadanya melalui proses pelacakan data dan informasi serta pemikiran yang logis, kritis, dan sistematis, (Slameto. 1991).

\section{METODE}

Penelitian yang dilakukan peneliti dalam penelitian ini adalah Penelitian Tindakan Kelas (Classroom Action Research). Penelitian tindakan yang dilakukan memiliki tujuan untuk meningkatkan hasil belajar peserta didik. Penelitian ini dilakukan dalam dua siklus, dan setiap siklusnya terdiri dari dua tindakan, sehingga semuanya berjumlah empat pertemuan, satu tindakan merupakan satu pertemuan.

Partisipan pada penelitian ini adalah siswa kelas V, yang berjumlah 30 siswa (17 laki-laki dan 13 perempuan). Instrumen dalam penelitian ini menggunakan instrumen JWAB (Jumlah Waktu 
Aktif Belajar) format observasi yang digunakan mengacu pada instrumen yang dikembangkan. Selain dengan menggunakan observasi digunakan pula obsevasi awal untuk menggali informasi dari guru pendidikan jasmani. Salah satu cara untuk mengetahui bagaimana siswa menghabiskan waktu dalam pelajaran penjas adalah dengan cara menganalisis waktu (time analysis) yang meliputi:

1) Manajemen (M) adalah waktu yang dihabiskan oleh sebagian besar siswa (lebihdari 50\%) melakukan aktifitas yang bersifat manajerial, misalnya pergantian bentuk latihan, menyimpan dan mengambil bola, mendengarkan aturan-aturan dalam mengikuti pelajaran, mendengarkan peringatan, ganti pakaian, dan kehadiran

2) Aktivitas belajar (A) adalah waktu yang dihabiskan oleh sebagian besar siswa (lebih dari 50\%) melakukan aktifitas belajar secara aktif.

3) Instruksi dan Demonstrasi (I) adalah waktu yang dihabiskan oleh sebagian besar siswa (lebihdari $50 \%$ ) untuk mendengarkan informasi bagaimana melakukan keterampilan (melihat demonstrasi, mendengarkan instruksi, penampilan).

4) Waktu tunggu (w) adalah waktu yang dihabiskan oleh sebagian besar siswa (lebih dari 50\%) tetapi tidak termasuk dalam ketiga kategori di atas (misalnya: tunggu giliran, sebagian besar siswa diam atau ngobrol tidak melakukan kegiatan yang ditugaskan, menunggu guru untuk memberikan instruksi) (Suherman. 2009).

Pengamatan GPAI (Game Performance Assessment Instrument), Oslin, dkk. 1998, Memmert dan Harvey. 2008), lembar observasi, catatan lapangan, dan rekaman foto.

\section{HASIL DAN PEMBAHASAN}

Penelitian dilakukan untuk mengetahui bagaimana hasil dari setiap tindakan yang dilakukan apakah keterampilan bermain dalam Soccer like games meningkat atau tidak. Dari hasil observasi awal yang telah diteliti oleh peneliti tersaji di dalam diagram I.

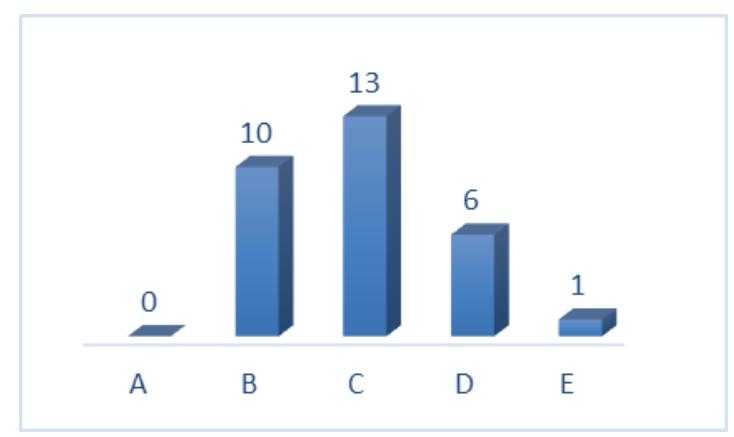

Gambar 1

Hasil Observasi Awal Keterampilan Bermain

Berdasarkan hasil observasi awal keterampilan bermain pada Gambar 1 nilai yang di peroleh predikat $\mathrm{A}$ hanya 0 orang $(0 \%), \mathrm{B}$ hanya 10 orang (33,33\%), C hanya 13 orang 43,33\%), D hanya 6 orang $(20,00 \%), E=1 \quad(3,33 \%)$. Dengan demikian dapat disimpulkan bahwa kemampuan keterampilan bermain siswa masih rendah dan jika dilihat dari nilai ketuntasan 75 maka nilai siswa dalam pencapaian ketuntasan hanya 10 orang yaitu 33,33\% siswa yang mencapai batas KKM.

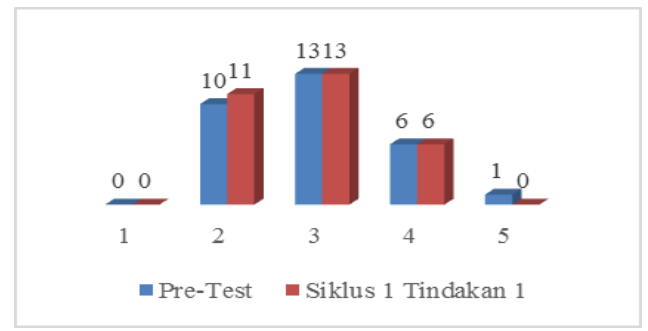

Gambar 2

Hasil Siklus 1 Tindakan 1

Keterampilan Bermain

Berdasarkan hasil siklus 1 tindakan 1 keterampilan bermain pada Gambar 2 nilai yang diperoleh predikat A hanya 0 orang $(0 \%)$, B hanya 11 orang $(36,67 \%)$, C hanya 13 orang $(43,33 \%)$, D hanya 6 orang $(20,00 \%)$, E hanya 0 orang $(0 \%)$. Dengan demikian dapat disimpulkan bahwa kemampuan keterampilan bermain siswa masih rendah dan jika dilihat dari nilai ketuntasan 75 maka nilai siswa dalam pencapaian ketuntasan hanya 11 orang yaitu $36,67 \%$ siswa yang mencapai batas KKM. 


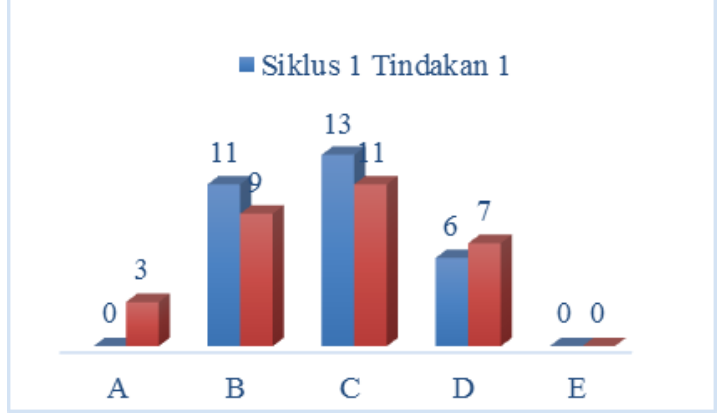

Gambar 3. Hasil Siklus 1 Tindakan 2

Berdasarkan hasil siklus 1 tindakan 2 keterampilan bermain pada Gambar 3 nilai yang diperoleh predikat A hanya 3 orang $(10,00 \%)$, B hanya 9 orang $(30,00 \%), \mathrm{C}$ hanya 11 orang $(36,67 \%), \mathrm{D}$ hanya 7 orang $(23,00 \%)$, E hanya 0 orang $(0 \%)$. Dengan demikian dapat disimpulkan bahwa kemampuan keterampilan bermain siswa masih rendah dan jika dilihat dari nilai ketuntasan 75 maka nilai siswa dalam pencapaian ketuntasan hanya 12 orang yaitu $40,00 \%$ siswa yang mencapai batas KKM.

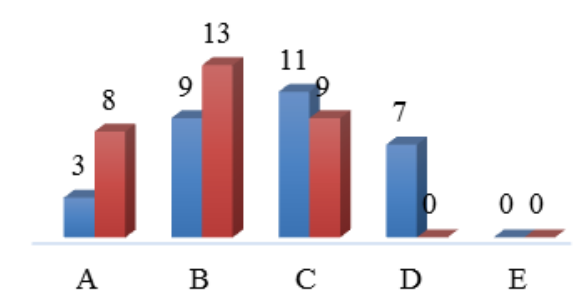

- Siklus 1 Tindakan 2 Siklus 2 Tindakan 1

Gambar 4 Hasil Siklus 2 Tindakan 1

Berdasarkan hasil siklus 2 tindakan 1 keterampilan bermain pada Gambar 4 nilai yang diperoleh predikat $A$ hanya 8 orang $(26,67 \%), \quad B$ hanya 13 orang (43,33\%), C hanya 9 orang (30,00\%), D hanya 0 orang $(0 \%)$, E hanya 0 orang $(0 \%)$. Dengan demikian dapat disimpulkan bahwa kemampuan keterampilan bermain siswa masih rendah dan jika dilihat dari nilai ketuntasan 75 maka nilai siswa dalam pencapaian ketuntasan hanya 22 orang yaitu
73.33\% siswa yang mencapai batas KKM.

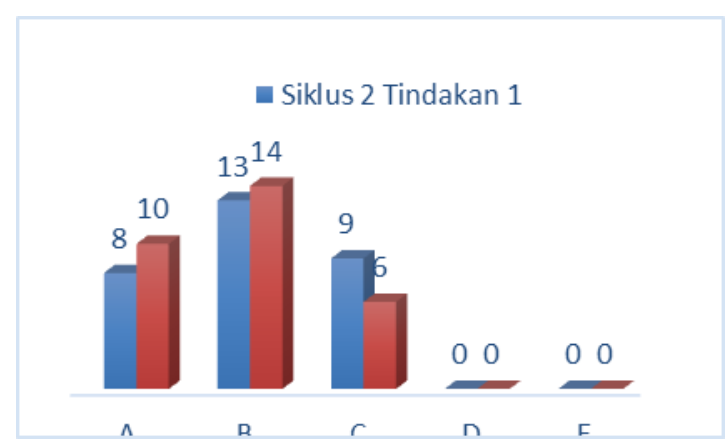

Gambar 5 Hasil Siklus 2 Tindakan 2

Berdasarkan hasil siklus 2 tindakan 2 keterampilan bermain pada Gambar 5 nilai yang diperoleh predikay A hanya 10 orang $(33.33 \%)$, B hanya 14 orang $(46.67 \%), \mathrm{C}$ hanya 6 orang (20.00\%), D hanya 0 orang $(0 \%)$, E hanya 0 orang $(0 \%)$. Dengan demikian dapat disimpulkan bahwa kemampuan keterampilan bermain siswa masih rendah dan jika dilihat dari nilai ketuntasan 75 maka nilai siswa dalam pencapaian ketuntasan hanya 24 orang yaitu $80.00 \%$ siswa yang mencapai batas KKM.

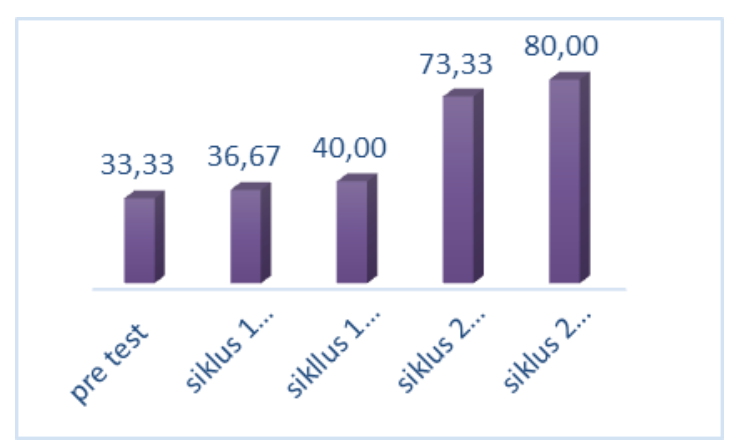

Gambar 6. Hasil Keseluruhan

Pada Gambatr 6 menunjukkan bahwa kemampuan siswa dalam melaksanakan atau menguasai keterampilan bermain mengalami peningkatan presentase setiap siklus dan tindakannya, pada pre-test presentase keseluruhan siswa sebesar (33.33\%), pada siklus 1 tindakan 1 presentase keseluruhan siswa (36.67\%), lalu pada siklus 1 tindakan 2 presentase keseluruhan siswa $(40,00 \%)$, 
kemudian siklus 2 tindakan 1 presentase keseluruhan siswa (73.33\%), pada akhir siklus 2 tindakan 2 presentase keseluruhan siswa $(80.00 \%)$. Dengan demikian proses pembelajaran keterampilan bermain yang diberikan dapat tercapai sesuai dengan tujuan pembelajaran yang diharapkan atau sesuai nilai ketuntatas.

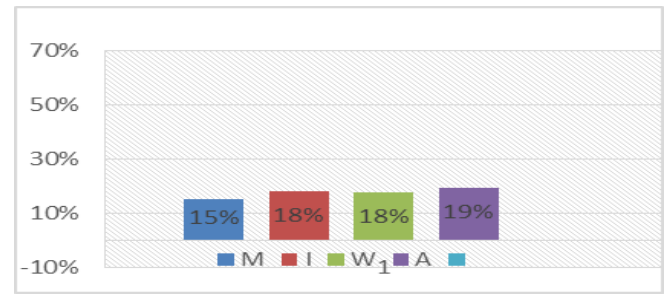

Gambar 7. Hasil Observasi Awal JWAB

Berdasarkan hasil observasi awal Jumlah Waktu Aktif Belajar pada Gambar 7 Waktu Management (M) (15,00\%), Waktu Intruksi (I) (18,00\%), Waktu Menunggu (W)( 17,70\%), Waktu Aktif (A) (19,30\%), Dengan demikian dapat disimpulkan jumlah waktu siswa masih rendah dan jika dilihat dari wakatu yang dihabiskan $50 \%$ pada setiap pembelajaranya dengan jumlah Presentase yang dihasilkan 27,57\% waktu yang diperoleh siswa selama PBM berlangsung.

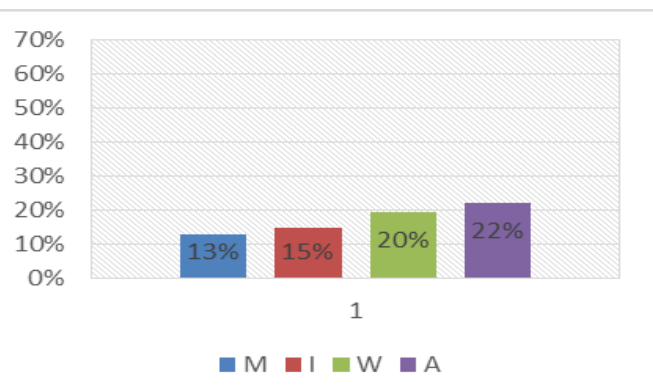

Gambar 8. Hasil Siklus 1 Tindakan 1 (JWAB)

Berdasarkan hasil observasi awal Jumlah Waktu Aktif Belajar pada Gambar 8 Waktu Management (M) (13,00\%), Waktu Intruksi (I) (15,00\%), Waktu Menunggu (W)( 19,53\%), Waktu Aktif (A) (22,27\%), Dengan demikian dapat disimpulkan jumlah waktu siswa masih belum mencapai kriteria karna Waktu aktif (A) masih rendah jika dilihat dari wakatu yang dihabiskan $50 \%$ pada setiap pembelajaranya dengan jumlah presentase yang dihasilkan 31,89\% waktu yang diperoleh siswa selama PBM berlangsung.

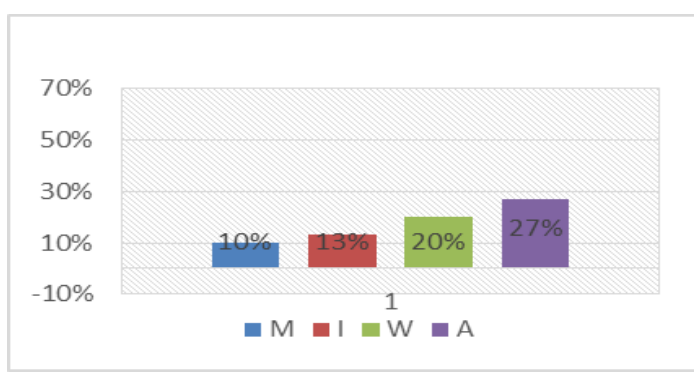

Gambar 9. Hasil Siklus 1 Tindakan 2 JWAB

Berdasarkan hasil observasi awal Jumlah Waktu Aktif Belajar pada Gambar 9 Waktu Management (M) (10,00\%), Waktu Intruksi (I) (13,00\%), Waktu Menunggu (W)( 19,90\%), Waktu Aktif (A) (27,03\%), Dengan demikian dapat disimpulkan jumlah waktu siswa masih belum mencapai kriteria karna Waktu aktif (A) masih rendah jika dilihat dari wakatu yang dihabiskan $50 \%$ pada setiap pembelajaranya dengan jumlah presentase yang dihasilkan $38,65 \%$ waktu yang diperoleh siswa selama PBM berlangsung.

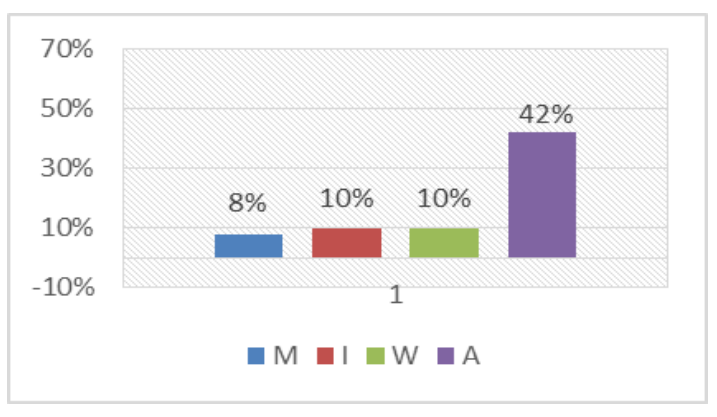

Gambar 10. Hasil Siklus 2 Tindakan $1 \mathrm{JWAB}$

Berdasarkan hasil observasi awal Jumlah Waktu Aktif Belajar pada Gambar 10 Waktu Management (M) (08,00\%), Waktu Intruksi (I) (10,00\%), Waktu Menunggu (W)( 10,00\%), Waktu Aktif (A) (42,10\%), Dengan demikian dapat disimpulkan jumlah waktu siswa masih belum mencapai kriteria karna Waktu aktif (A) masih rendah jika dilihat dari 
wakatu yang dihabiskan $50 \%$ pada setiap pembelajaranya dengan jumlah presentase yang dihasilkan $60,14 \%$ waktu yang diperoleh siswa selama PBM berlangsung.

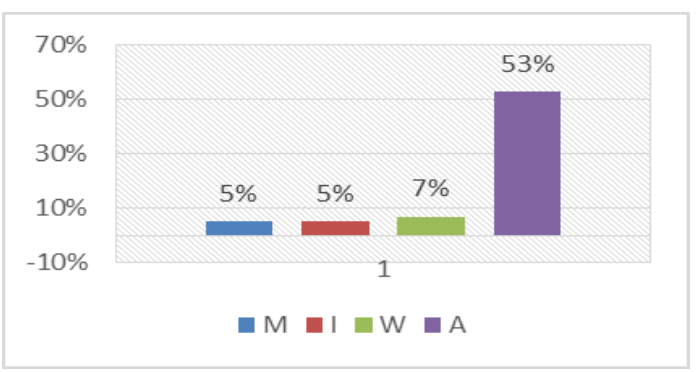

Gambar 11. Hasil Siklus 2 Tindakan 2

Berdasarkan hasil observasi awal Jumlah Waktu Aktif Belajar pada Gambar 11 Waktu Management (M) (05,00\%), Waktu Intruksi (I) (05,00\%), Waktu Menunggu (W)( 07,00\%), Waktu Aktif (A) (53,07\%), Dengan demikian dapat disimpulkan jumlah waktu siswa masih sudah mencapai kriteria karna Waktu aktif (A) sudah melebihi batas jika dilihat dari wakatu yang dihabiskan lebih dari $50 \%$ pada setiap pembelajaranya dengan jumlah presentase yang dihasilkan 75,81\% waktu yang diperoleh siswa selama PBM berlangsung.

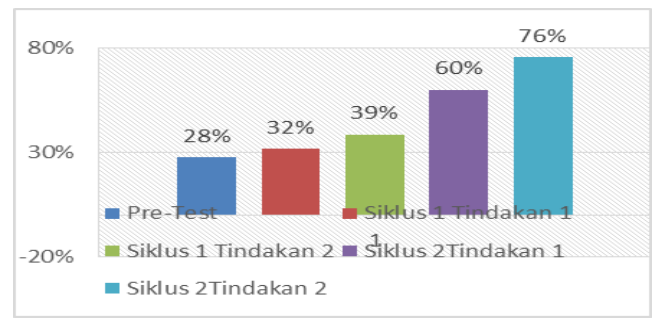

Gambar 12. Hasil Akhir Penelitian

Berdasarkan hasil akhir penelitian pada tabel Gambar 12 menunjukkan jumlah waktu yang dihabiskan siswa mengalami peningkatan presentase setiap siklus dan tindakannya, pada pre-test presentase keseluruhan siswa sebesar $(27.57 \%)$, pada siklus 1 tindakan 1 presentase keseluruhan siswa
(31.89\%), lalu pada siklus 1 tindakan 2 presentase keseluruhan siswa $(38,65 \%)$, kemudian siklus 2 tindakan 1 presentase keseluruhan siswa (60.14\%), pada akhir siklus 2 tindakan 2 presentase keseluruhan siswa (75.81\%). Dengan demikian jumlah waktu aktif belajar telah tercapai sesuai dengan tujuan pembelajaran yang diharapkan atau sesuai nilai ketuntatas.

Penerapan model inkuiri dalam Soccer like games sangat cocok diterapkan di sekolah dasar, karena memberikan mereka kesempatan untuk menggunakan keterampilan yang mereka miliki dalam suasana pembelajaran yang menyenangkan dengan mensimulasikan permainan yang sebenarnya dan memungkinkan peserta didik untuk mengembangkan keterampilan dasar agar berhasil dalam memainkan permainan yang sebenarnya. Dengan pembelajaran Soccer like games yang merupakan permainan yang tergolong sudah tidak asing dikalangan anak pada tingkat sekolah dasar serta media yang bisa di modifikasi. Hal ini membantu dalam proses pembelajaran menjadi semakin menarik dan tentunya berguna bagi tumbuh kembang siswa. Hal ini sejalan dengan pendapat Trianto (dalam Juliantine, dkk. 2015) bahwa "model inquiry sebagai suatu proses umum yang dilakukan manusia untuk mencari atau memahami informasi.

Sementara itu, pembelajaran Soccer like games juga berperan pada proses pembelajaran pendidikan jasmani ini. Karena dengan pembelajaran Soccer like games, dapat menigkatkan jumlah waktu aktif belajar anak serta mengasah keterampian bermain anak dan siswa dituntut untuk memiliki sikap tanggung jawab terhadap diri sendiri, maupun tanggung jawab terhadap orang lain, juga dituntut untuk saling membantu, saling menghargai teman, disiplin, dan sifat positif lainnya yang diharapkan dapat direalisasikan dalam kehidupan sehari-hari, tidak hanya dalam pembelajaran pendidikan jasmani saja. 


\section{KESIMPULAN}

Terdapat peningkatan jumlah waktu aktif belajar dalam pembelajaran soccer like games melalui model inquri pada siswa kelas V. Implikasi di lapangan peneliti temukan dalam pembelajaran, yaitu memberikan kesempatan untuk siswa dalam mengeskpresikan diri dan memberikan mereka kesempatan untuk menggunakan keterampilan yang mereka miliki.

\section{DAFTAR PUSTAKA}

Amin, D. I., \& Sigit, D. (2018). Instrumen Asesmen Pemahaman Konseptual Berorientasi Higher Order Thinking Skills Keterampilan Proses dan Sikap terhadap Sains pada Bahan Kajian Hidrokarbon dan Minyak Bumi. (2017), 1142-1146.

Arikunto, S. (2006a). Prosedur Penelitian Suatu Pendekatan Praktik. Jakarta: PT Rineka Cipta.

Arikunto, S. (2009b). Prosedur Penelitian Suatu Pendekatan Praktik. Jakarta: PT Rineka Cipta.

Bahagia, Y. \& Mujianto, S. (2010). Fasilitas dan Perlengkapan Penjas. Bandung: FPOK UPI

Endarti, A. (2016). Penerapan Metode Pembelajaran Inquiry untuk Meningkatkan Hasil Belajar dan Sikap Siswa pada Mata Pelajaran Boga Dasar Kelas X-JBG-3 SMK N 4 Yogyakarta. Universitas Negeri Yogyakarta

Hidayat, T. (2017). Pembelajaran Soccer like games Dalam Meningkatkan Keterampilan Dasar Sepakbola Pada Siswa Di Smpn 1 Karawang. Judika (Jurnal Pendidikan Unsika)

Lahadisi. (2014). Inkuiri: Sebuah Strategi Menuju Pembelajaran Bermakna. Jurnal Al-Ta'dib Vol. 7 No. 2 Juli-Desember 2014.

Mahendra, A. (2015). Filsafah Pendidikan Jasmani. Bandung: CV. Bintang Warliartika.

Mappeasse, M. Y. (2009). Pengaruh Cara dan Motivasi Belajar Terhadap Hasil Belajar Programmable Logic Controller (PLC) Siswa Kelas III Jurusan Listrik SMK Negeri 5 Makassar. Jurnal Medtek, 1(2), 1-6.
Mardotillah, M., \& Zein, D. M. (2017). Silat: identitas budaya, pendidikan, seni bela diri, dan pemeliharaan kesehatan. 18(2), 121-133.

Memmert, D. \& Harvey, S. (2008) The Games Performance Assesment Instrument (GPAI): Some Concers and solutions for the futher Development. Journal of Teaching Physical Education.

Sugiyono. (2017). Metode Penelitian Kuantitatif Kualitatif dan $R \& D$. Bandung: Alfabeta.

Suntoda, A. (2017). Upaya Menigkatkan Jumlah Waktu Aktif Belajar Melalui Penerapan Pengajaran Peer Teaching dalam Pembelajaran Tennis. Vol. 12 No. 2

Stephani, M. R., Nur, L., Hambali, B., Suherman, A., \& Subarjah, H. Comparative Analysis of Student Learning Motivation and Motion Intensity in Tactical and Technical Learning Models in Invation Games. Jurnal Pendidikan Jasmani dan Olahraga. 4(2), 225-230.

Stephani, M. R. (2017). Stimulasi Kemampuan Berpikir Kritis Melalui Pembelajaran Berbasis Masalah Pada Pendidikan Jasmani. Jurnal Pendidikan Jasmani Dan Olahraga, 2(1), 16 $-27$.

Stephani, M. R., Suherman, A., \& Mulyana, R. B. (2014). Pengaruh Model Pembelajaran Inkuiri terhadap Kemampuan Berpikir Kritis dan Keterampilan Bermain Bola Basket. Edusentris, 1(2), 156-170.

Juliantine, T., \& Arifin, F. The Effect of Learning Model and Intelligence Quotient on Critical Thinking and Handball Games Performance. Jurnal Pendidikan Jasmani Dan Olahraga, 4(1), 37-42. 